\title{
汀線位置変動に及ぼす周波数別波浪および 前浜形状の影響 \\ A STUDY ON SHORELINE CHANGE RATE DUE TO WAVE AND FORESHORE SHAPE
}

\author{
鈴木崇之 \\ Takayuki SUZUKI \\ 正会員 博(工) 横浜国立大学准教授 大学院都市イノベーション研究院 \\ （干240-8501 神奈川県横浜市保土ヶ谷区常盤台79-5)
}

\begin{abstract}
In this paper, correlations between shoreline change rates and six frequency-sectioned wave energy fluxes were discussed using a 5-year data set of beach profiles and offshore waves observed at the Hasaki coast. Also, an effect of foreshore beach shape on shoreline backward movement speed was discussed. From the results, it is possible to separate shoreline erosion events from shoreline advance events and shoreline stand still events by using frequencysectioned wave energy fluxes. Furthermore, the results revealed that the shoreline position and foreshore shape affect shoreline backward movement speed. This indicates that for the estimation of the shoreline change rate, we need to consider not only wave energy but also shoreline position and foreshore shape.
\end{abstract}

Key Words : Shoreline change rate, wave energy flux, foreshore shape, berm

\section{1.はじめに}

汀線位置は砕波帯内での波・流れの影響を受けて 地形が変化することに伴い, 静穏時には前進し, 荒 天時には後退する. この汀線位置の変動を把握し, さらに予測することは海岸保全のみならず海岸管理 という面からも重要である。この汀線位置の変動を 把握するにあたり，波浪との関係についてはこれま でにも多くの研究者によりなされている，また，底 質粒径の関係例えば，1)，沿岸砂州の影響2) といった面 からの検討も行われている.さらに，汀線位置変動 予測においても, 数年から数十年の長期変動例えば, 3) や，数日から数力月の短期変動例えば，4)についても 成果が報告されている。

ここで, 地形変化や汀線位置変動に及ぼす周期帯

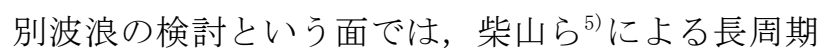
波の漂砂に及ぼす影響や，加藤ら ${ }^{6)}$ による長周期波 の遡上により波打ち帯が侵食されることなどが報告 されている。しかしながら，これらは周期が30秒程 度以上の長周期波とそれよりも周期が短い波という 区分での評価がほとんどである.

そこで, 本研究では5年間分の地形断面データ, および波浪データを用いて, 汀線位置変動と周波数 帯別波浪の関係について検討した。ささらに, 汀線後 退イベントに着目し, 汀線後退速度と前浜地形形状
との関係についても検討を行った.

\section{2. 現地観測データの概要}

解析には, 茨城県波崎海岸に位置し（独）港湾空 港技術研究所が所有する波崎海洋研究施設にて計測 された地形断面データ，および鹿島港沖にて計測さ れた波浪データのうち，2001 年 1 月から 2005 年 12 月（5年間）までを使用した。

波崎海洋研究施設（以下HORS，図-1）では，長さ $427 \mathrm{~m}$ の観測栈橋に沿って, 休日を除く 1 日 1 回地 形断面を計測している．陸上部はスタッフとオート レベルを用いて測量し, 海域部は栈橋上から質量約 $3 \mathrm{~kg}$ のッドを降ろし, 海底面から栈橋までの距離 を用いて測量を行っている。また，沖波波浪は鹿島 港沖の水深約 $24 \mathrm{~m}$ の地点（図-1）に設置された超音 波式波高計により，2 時間毎に観測されている.

解析に使用した 5 年間の平均地形断面とその標準 偏差を図-2に示す。なお，岸沖方向位置 (x) はHORS 固有の座標軸であり，沖向きを正としている。また， 高さの基準(D. L. ) は波崎港工事基準面 (T. P. - - 687 m) であり，観測地点における干潮位，平均潮位，満 潮位はそれぞれ-0.20 m， $0.65 \mathrm{~m} ， 1.25 \mathrm{~m}$ である. 解析期間中の平均地形断面と満潮位が交わる岸沖方 向距離はx $=5.77 \mathrm{~m}$ であった. HORS周辺の底質粒径 
は岸沖方向にほぼ一様であり, その中央粒径は 0.18 $\mathrm{mm}$ である $\left(\right.$ 加藤ら ${ }^{7)}$ ) . 図中, $\mathrm{x}=0 \mathrm{~m} \sim 25 \mathrm{~m}$ の範 囲で標準偏差がやや高くなっているが，これは汀線

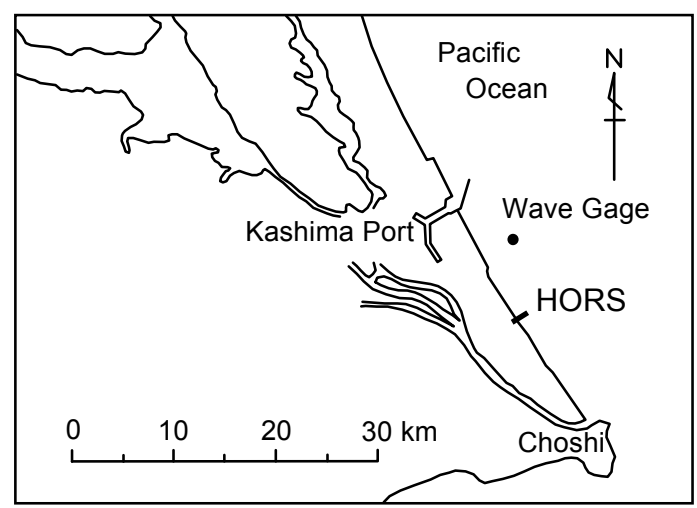

図-1 波崎海洋研究施設（HORS）および沖波波浪観測点 の位置

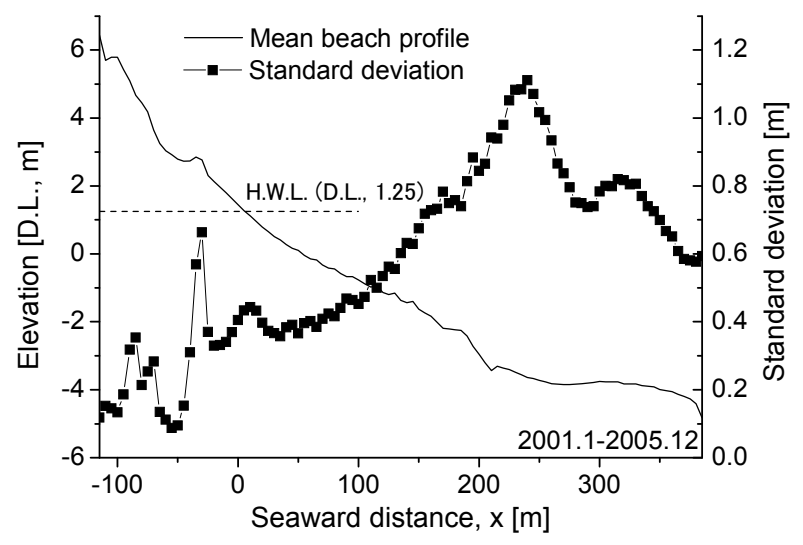

図-2 解析期間中の平均地形断面 (D.L. 基準) およびそ の標準偏差
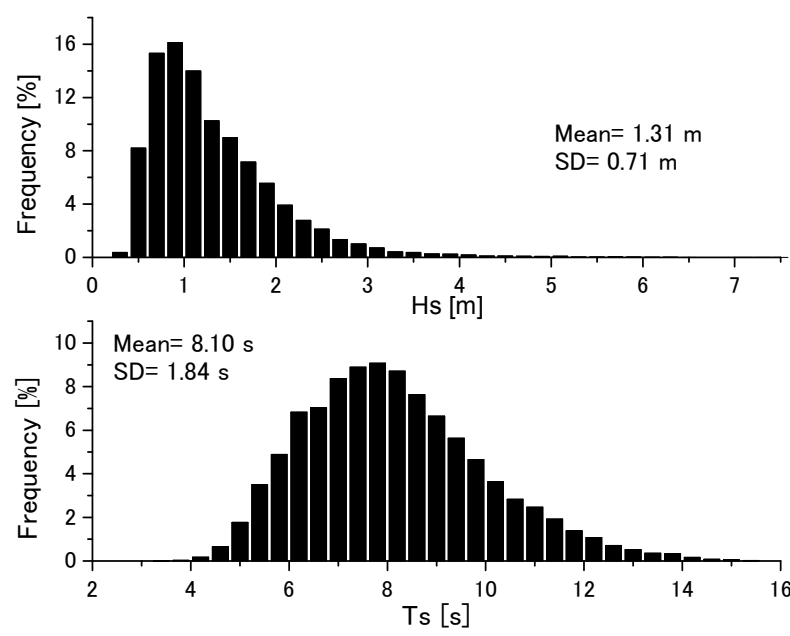

図-3 解析期間中の有義波高（Hs）および有義波周期 （Ts）の日平均值の頻度分布
付近においてバームの形成, 消失が起っているため である。また， $\mathrm{x}=240 \mathrm{~m}$ 辺りを中心とした高い標 準偏差は，バーの移動に伴う地形変化の影響である. 加えて, $\mathrm{x}=-30 \mathrm{~m}$ 辺りのピークは, 観測栈橋斜路 の背後地に堆積した飛砂よるものである.

鹿島港沖にて計測されている沖波波浪は，全国港 湾海洋波浪情報網（NOWPHAS；例えば，永井 ${ }^{8)}$ ）の 観測点の 1 つである。計測結果から算出した, 解析 期間中における有義波高，および有義波周期の日平 均值の頻度分布を図-3に示す。解析期間中, 有義波 高は0. $39 \mathrm{~m}$ から5.66 mの幅で変動し, 有義波周期は $4.70 \mathrm{~s}$ から $14.3 \mathrm{~s}$ の幅で変動していた。それぞれの 平均值は $1.31 \mathrm{~m}, 8.10 \mathrm{~s}$ であった。

\section{3. 汀線位置および周波数帯別波高の算出}

\section{（1）汀線位置}

汀線位置は波崎海岸にて計測された地形断面デー タから求めた。本研究では，地盤高が対象海岸にお ける満潮位であるD. L. + $1.25 \mathrm{~m}$ の高さを有する岸沖 方向地点と定義した。この地点の変動は, 飛砂に よって生じた地形変化の位置 $(\mathrm{x}=-30 \mathrm{~m}$ 辺り $)$ よ りも海側であり，本解析ではこの影響は受けていな い.

解析期間中における汀線位置の変動を図-4に示す. 平均汀線位置はx $=6.05 \mathrm{~m}$ であり，標準偏差は 11.6 $\mathrm{m}$ であった。汀線位置の変動は多少のばらつきはあ るものの季節変動が見られ, 冬季から夏季にかけて 前進し, 秋季から冬季にかけて後退していることが わかる。この季節変動の傾向は, HORSでの15年間分 のデータを解析した鈴木・栗山到と同一傾向である。

次に, 汀線位置の日々の変化速度を基に後退時, 停滞時, 前進時の変動イベントの抽出を行う。汀線 位置変動から算出した汀線位置変化速度の頻度分布 を図-5に示す。ここで，負は汀線位置の後退，正は

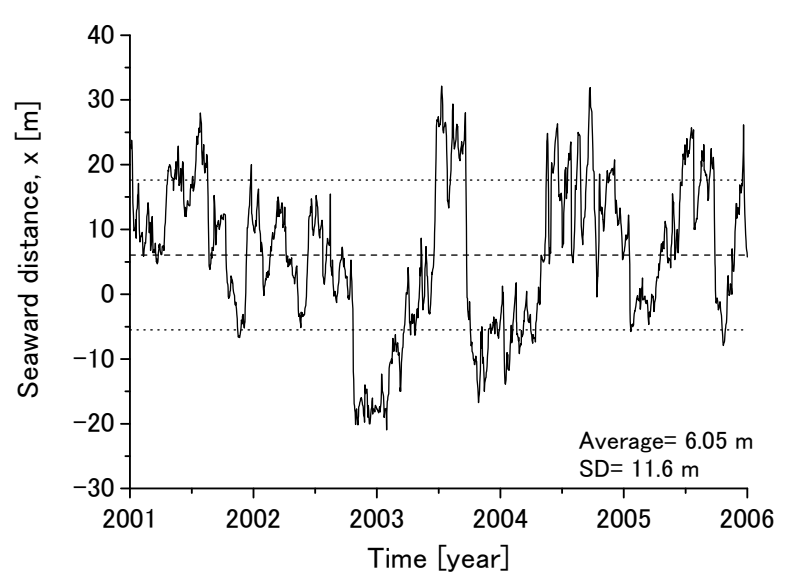

図-4 汀線位置の変動（破線：平均汀線位置，点線：標準 偏差） 
前進を示す. 変化速度の平均值は- $0.01 \mathrm{~m} /$ dayであ り，その標準偏差は $1.45 \mathrm{~m} /$ dayであった。後退時 （変化量が負）は765日あり，その平均值は-1. 13 m/day, 標準偏差は $1.36 \mathrm{~m} /$ dayであった。一方, 前 進時（変化量が正）は994日あり，その平均值は $0.85 \mathrm{~m} /$ day, 標準偏差は $0.86 \mathrm{~m} /$ dayであった.

ここで, 汀線後退イベントの抽出条件として, 後 退時の平均変化速度 $(-1.13 \mathrm{~m} / \mathrm{day})$ よりも後退が速 い日が3日以上連続した場合とし，また，汀線前進 イベントの抽出条件は, 前進時の平均変化速度

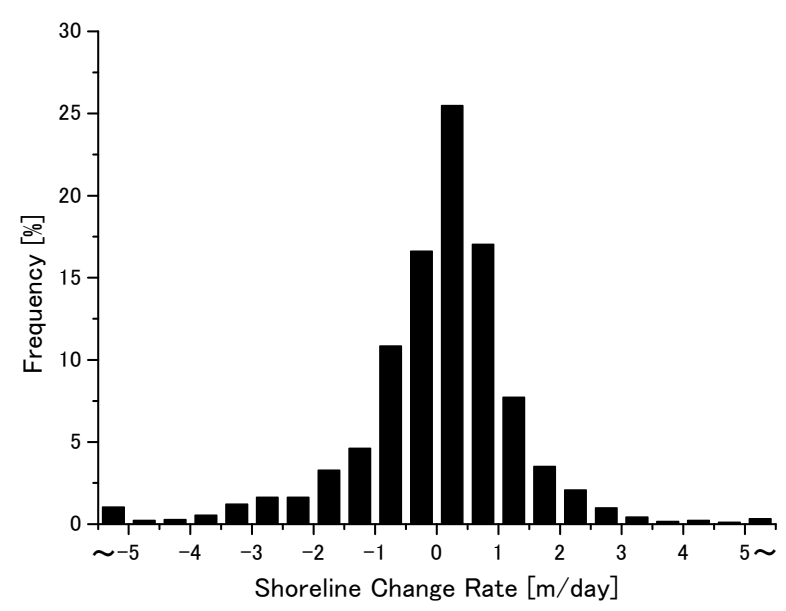

図-5 汀線位置変化速度の頻度分布

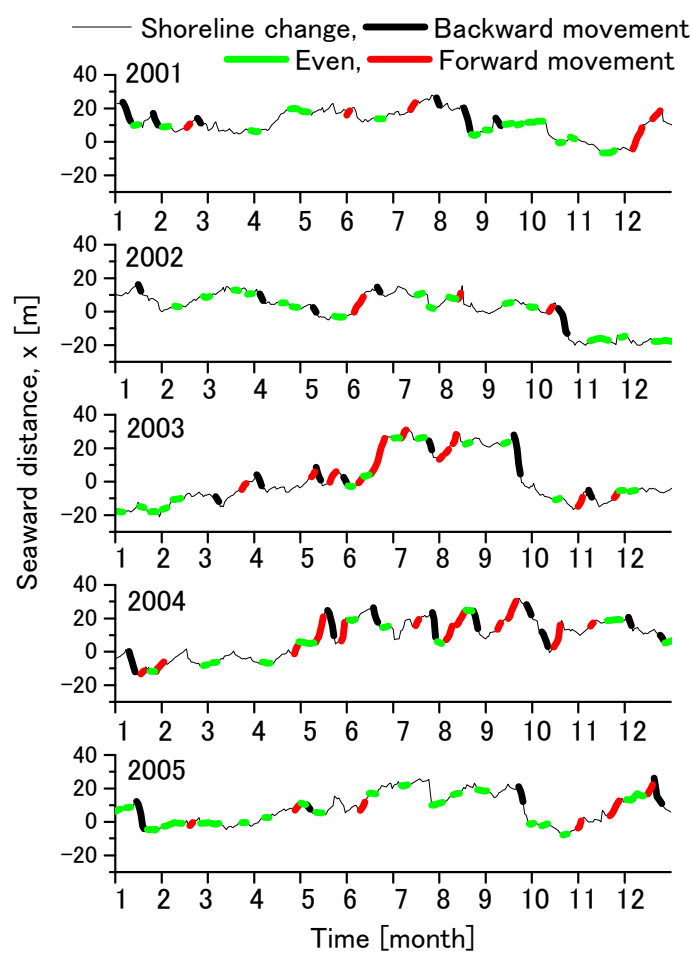

図-6 汀線位置変動（黒細線）および抽出された汀線位置 の後退（黒太線）, 停滞（緑太線）, および前進イ ベント（赤太線）
(0.85 m/day)よりも前進が速い日が 3 日以上連続し た場合とした，停滞時については，変化速度が-0.5 $\mathrm{m} /$ day以上 $0.5 \mathrm{~m} /$ day未満が 4 日以上連続した場合と した. 今回の判断基準により抽出されない期間につ いては，各イベント間の変移期と捉えることとし， 解析から除外した. 抽出結果を汀線変動の時系列上 に重㸚合わせたものを図-6に示す。後退イベント， 停滞イベント，前進イベントはそれぞれ31，75，37 ケース抽出され，それぞれの平均継続日数は 4.0 , 4. 4，4.3日であった.

\section{（2）周波数帯別波高}

鹿島港沖にて観測された波高データは，スペクト ル解析により区分された周波帯数ごとの波高も算出 されている ${ }^{10)}$.この周波数帯別波高は，周波数スペ クトルにおいてその周波数帯のエネルギーを積分し て求められたものであり, その周波数帯での有義波 高に相当する波高である. そこで, 本研究では有義 波高に加えて，この周波数帯別波高も解析に用いる こととした。波高は周波数帯別にf1からf6まで6段 階に区分されており，それぞれの周期帯は 32.0 秒以 上 (f1)，16.0〜25. 6秒 (f2)，10.7〜14.2秒 (f3), 8. $0 \sim 9.8$ 秒 $(\mathrm{f} 4), 4.3 \sim 7.5$ 秒 $(\mathrm{f} 5), 4.1$ 秒以下 $(\mathrm{f} 6)$ となっている ${ }^{10)}$. ただし，データの久測期間を解析 から除外したため, 2001年から2005年の各年のデー 夕取得率はそれぞれ $96.7 \%$ ，100.0％，100.0\%， 79.0 \%， 98.8 \%となった.

解析期間中における有義波高 (Hs) および周波数 帯ごとに区分された波高（周波数帯 $\mathrm{f} 1$ 〜 f6の波高を それぞれHf1～Hf6とする）の平均波高，標準偏差， 最大・最小波高を表-1に示寸.

解析では，有義波高，および区分された周波数帯 別波高ごとに波浪エネルギーフラックスを栗山・伊 東 ${ }^{11)}$ に倣い算出した。有義波高と有義波周期を用い て算出した波浪エネルギーフラックス（Ef）に加え， 各周波数帯のエネルギーフラックスについても, 各 周波数帯の中央周期（中央值）を用いて, Ef1（周 期帯f1），Ef2（周期帯f2），Ef3（周期帯f3）, Ef4（周期帯f4）， Ef5（周期帯f5）， Ef6（周期帯 f6）を算出した.

表-1 解析期間中における有義波高 $(\mathrm{Hs})$ および周波数別 波高 $(\mathrm{Hf} 1 \sim \mathrm{Hf} 6)$ の統計值

\begin{tabular}{c|c|c|c|c}
\hline & $\begin{array}{c}\text { 平均波高 } \\
{[\mathrm{m}]}\end{array}$ & $\begin{array}{c}\text { 標準偏差 } \\
{[\mathrm{m}]}\end{array}$ & $\begin{array}{c}\text { 最大波高 } \\
{[\mathrm{m}]}\end{array}$ & $\begin{array}{c}\text { 最小波高 } \\
{[\mathrm{m}]}\end{array}$ \\
\hline Hs & 1.31 & 0.71 & 7.50 & 0.31 \\
\hline Hf1 & 0.09 & 0.06 & 0.90 & 0.02 \\
\hline Hf2 & 0.24 & 0.26 & 4.18 & 0.05 \\
\hline Hf3 & 0.67 & 0.52 & 5.18 & 0.11 \\
\hline Hf4 & 0.65 & 0.38 & 3.51 & 0.13 \\
\hline Hf5 & 0.78 & 0.43 & 2.93 & 0.15 \\
\hline Hf6 & 0.47 & 0.21 & 1.23 & 0.11 \\
\hline
\end{tabular}




\section{4. 汀線位置変動と周波数帯別波浪エネル ギーフラックスとの関係}

汀線位置の変化量により区分された後退, 停滞, および前進イベントの変動開始前の汀線位置と有義 波高のエネルギーフラックスとの関係を図-7に示す。 ただし，エネルギーフラックスはイベント継続日数 の平均值である。また，周波数帯別波高の久測によ り, 解析に用いた後退, 停滞, 前進イベント数はそ れぞれ31，69，37となった。

停滞イベント（三角印）と前進イベント（丸印） については, 前進イベントが停滞イベント時のエネ ルギーフラックスに挟まれる形で分布しているよう にも見える. 砂村 ${ }^{12)}$ は, 汀線位置の前進後退の変動 を波高の2次曲線として提案している. 図-7からは 明瞭な分離は困難ではあるが，その傾向は伺える.

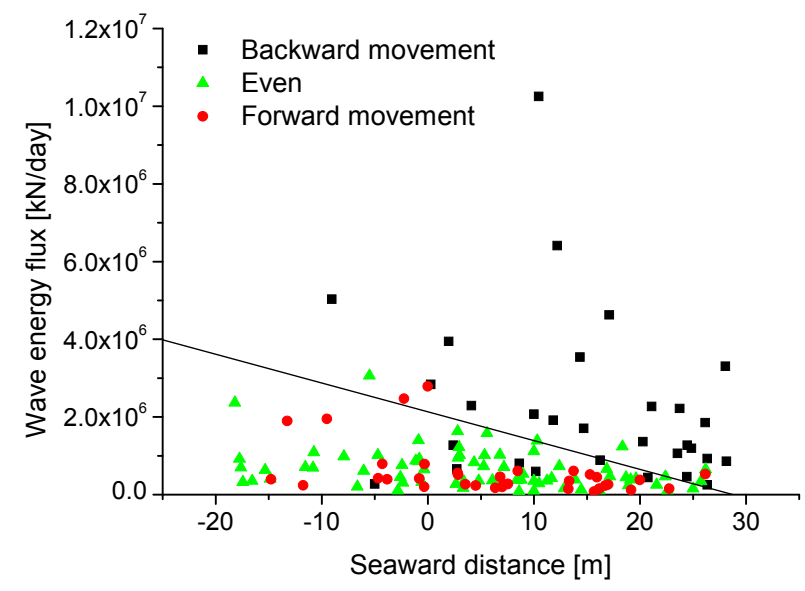

図-7 後退, 停滞, 前進イベントごとに算出した汀線位置 と有義波高のエネルギーフラックスとの関係（実線 は後退時と停滞および前進時の判別直線)

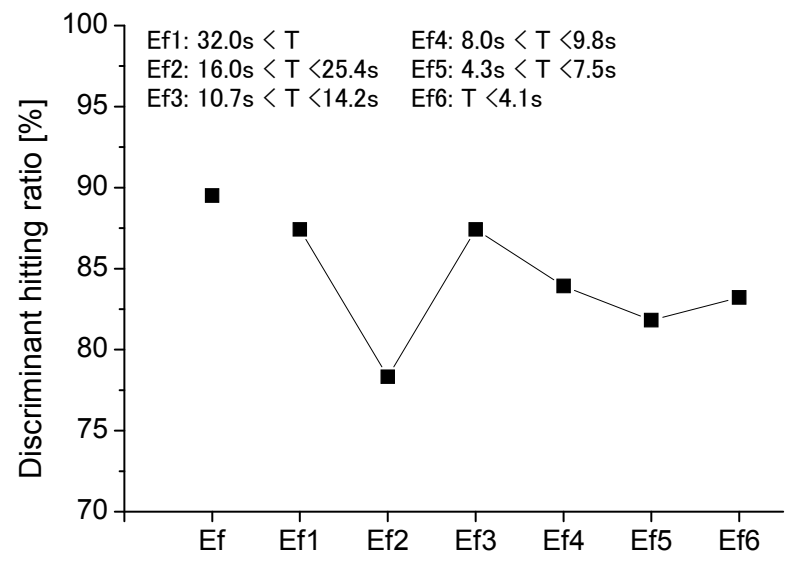

図-8 有義波高のエネルギーフラックスおよび周波数帯別 エネルギーフラックスによる後退イベントと停滞・ 前進イベントの判別的中率
一方，汀線位置後退イベント時（四角印）の沖波 エネルギーフラックスは, 停滞および前進イベント 時のそれに比べて值が大きく，また，汀線位置が沖 にあるときほど小さなエネルギーフラックスでも汀 線位置が後退していることがわかる.

図中の実線は判別分析から求められた後退イベン トと停滞および前進イベントの判別直線であり,こ の直線により汀線位置の後退イベントと停滞もしく は前進イベントを $94.4 \%$ の確率（判別的中率=一致 数／全数×100）で判別可能であることがわかった。

これまでにも，沖波エネルギーフラックスの大小 を用いた汀線位置変動モデルは提案されており 6), 13), 14)，本解析はこれらを支持する結果となった。 一方, 停滞時と前進時については, 沖波エネルギー フラックスによる分離は困難に見える.

次に，周波数帯別波浪エネルギーフラックスを用 いて図-7と同様に汀線位置の後退イベントと停滞・ 前進イベントの判別を行った。周波数帯別エネル ギーフラックスを用いて行った判別的中率，および 有義波高のエネルギーフラックスによる判別的中率 を図-8に示す．図より，32秒以上の周期帯である $\mathrm{f} 1$, および10.7 秒〜 14.2 秒の周期帯である $\mathrm{f} 3$ での的中率 が高いことがわかる. しかし，16.0秒～25. 6秒の周 期帯であるf 2 での的中率が低くなっている. 加藤ら ${ }^{15)}$ は，波崎海岸において計測した沖波波高を用いて スペクトル解析を行っており，そこでもこの周波数 帯のエネルギーフラックスの低下がみられた。この 理由として, Ef2の周期帯（16.0 秒〜25.6秒）が観 測を実施している波崎海岸一帯に来襲する波浪の代 表周期と代表長周期の狭間に位置し，他の周波数帯 に比べて来襲頻度（エネルギーフラックスのパ ワー）が小さいためと考えられる.

ここで, 有義波高 $(\mathrm{Hs})$ と各周波数帯別波高 $(\mathrm{Hf} 1$ 〜 Hf6）との相関を図-9に示す．32秒以上の長周期帯で 最も高い相関関係が見られた。このように長周期波 を有義波高で説明できることは加藤ら ${ }^{15)}$ も指摘して いる. さらに, 8.0 秒 9.8 秒のf4周波数帯で高い相

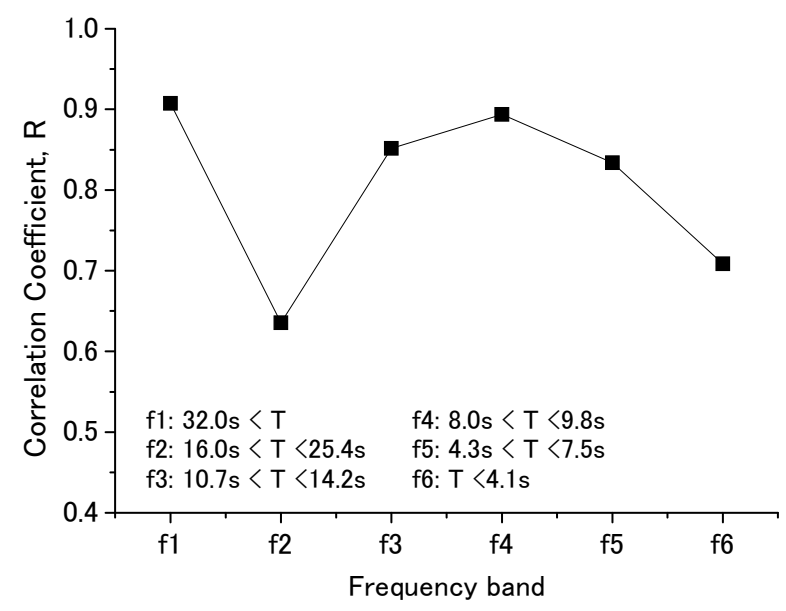

図-9 有義波高 $(\mathrm{Hs})$ と各周波数帯波高 $(\mathrm{Hf} 1 \sim \mathrm{Hf} 6)$ との相関 


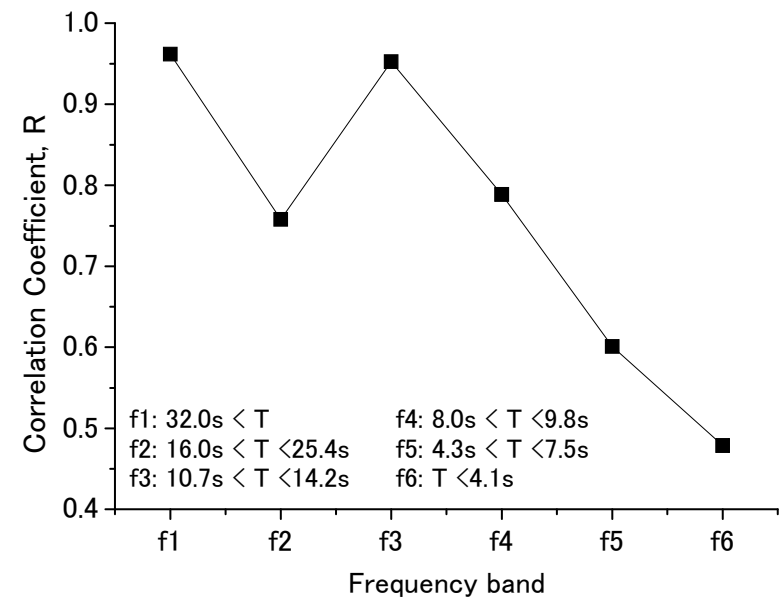

図-10 有義波高から算出したエネルギーフラックス (Hf) と各周波数帯エネルギーフラックス $(\mathrm{Hf} 1 \sim \mathrm{Hf} 6)$ と の相関

関関係が見られ，また，解析に用いた波浪データの 平均周期 (8.10秒) 前後 $(f 3, f 5)$ においても良い相 関関係が見られた。f2周波数帯（16.0 秒〜25.6秒） については他と比較しても相関係数は低くなってい ることがわかる．表-1の平均值と標準偏差からもか らわかるように, f2 周波数帯では他の周波数帯に比 べてばらつきが大きく，これが低下の一因であると 考えられる。

次に，有義波高から算出したエネルギーフラック ス $(\mathrm{Ef})$ と各周波数帯のエネルギーフラックス $(\mathrm{Ef} 1$ 〜 Ef6）との相関を図-10に示す。こちらも波高の相関 関係と同様にf2周波数帯で低い相関となっている. また，相関のピークはf3周波数帯（10.7秒〜 14.2 秒）であった。

\section{5. 汀線後退と地形形状との関係}

汀線後退イベントは, 有義波高, および $\mathrm{f}$, f f 周 波数帯より算出した沖波エネルギーフラックスによ り $85 \%$ 以上の的中率で抽出が可能であることがわ かった（図-8）。ここで，各後退イベントの後退速 度とイベント発生時の汀線位置の関係を図-11に示 す. 後退速度が-3. 0 m/dayよりも速い後退イベント に着目すると，すべてのイベントの汀線位置がx =

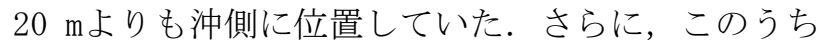
$67 \%$ 前浜に形成される堆積性地形であるバームの 侵食を伴う後退であった。ここで，図中四角印が バーム侵食を伴う汀線位置の後退である.

次に, バームが最も発達した時の地形形状と, バームが侵食した後の地形形状の差（鉛直地形変化 量）の最大值をバーム高と定義し，バーム高と汀線 位置の後退速度との関係を図-12に示す。バーム高 が高くなるほど後退速度が増す傾向が見られた $(\mathrm{R}=$ $0.61)$. 汀線後退時, バームの侵食が伴う場合の平 均後退速度は-3. $3 \mathrm{~m} /$ dayであり, 伴わない場合は一 $2.1 \mathrm{~m} /$ dayであり, 両者の速度には約 1.6 倍の差があ
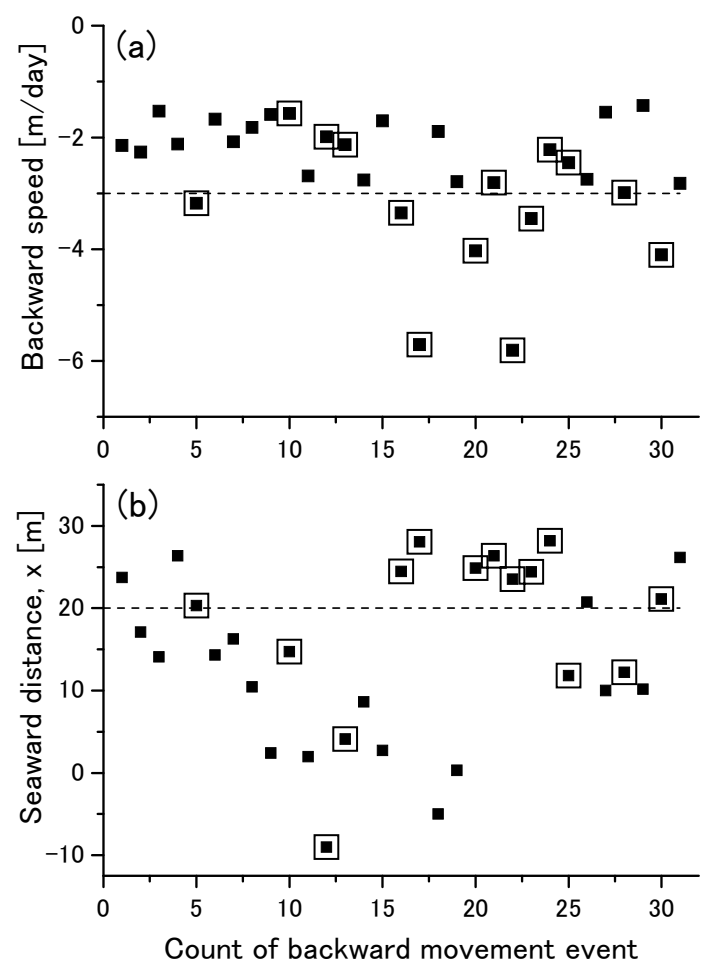

図-11 各後退イベントの汀線後退速度 (a) と後退直前の汀 線位置(b)（口はバームの侵食が伴ったケース）

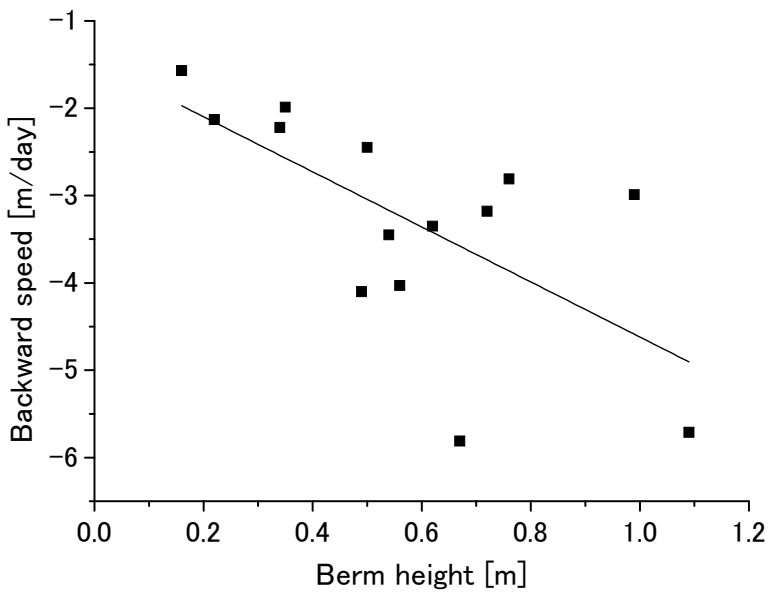

図-12 バーム高と後退速度との関係

ることがわかった。

これは, 汀線位置変動を予測する際などには, バームといった汀線近傍（前浜）に形成される地形 形状の影響を加味しなければならないことを示唆し ている.

\section{6. まとめ}

波崎海洋観測施設に計測された5年間の地形断面 
データを用いて, 汀線位置変化量から後退, 停滞, 前進イベントを抽出した。 これらのイベントと鹿島 港沖にて観測された波浪データを用いて, 汀線位置 変動と周波数帯別波浪との関係を検討した。 その結 果，汀線位置の停滞イベントと前進イベントの分離 は困難であるけれども, 後退イベントと停滞・前進 イベントの分離については, 有義波高のエネルギー フラックス，または，波浪スペクトル密度の高い周 波数帯のエネルギーフラックスにより可能であるこ とがわかった。さらに, 抽出した汀線後退イベント を用いて, 汀線後退速度と前浜地形形状（バームの 有無）との関係についての検討により, 汀線位置変 動の予測には, 汀線の岸沖方向位置に加えて地形形 状も考慮する必要があることを示唆された。

謝辞 : 本研究を実施するにあたり，（独）港湾空港 技術研究所, 栗山善昭特別研究官, 海洋水工部中村 聡志上席研究官, ならびに沿岸土砂管理研究チーム の中川康之チームリーダーをはじめとするチームメ ンバーには貴重なご意見を頂いた。本研究で使用し た地形断面データは波崎海洋研究施設に常駐した港 湾空港技術研究所沿岸土砂管理研究チームのメン バーならびに侏プライア・コンサルタントの観測補 助員によって取得されたものである. また, 沖波波 浪データは国土交通省関東地方整備局鹿島港湾・空 港整備事務所と独立行政法人港湾空港技術研究所海 象情報研究チームより提供されたものである.ここ に記して謝意を表する. 本研究の一部は科学研究費 補助金（若手研究B）によるものである.

\section{参考文献}

1) Mason, T. and Coates, T. T. : Sediment transport processes on mixed beaches: A review for shoreline management, J. Coastal Res., Vol. 17, No. 3, pp. 645-657, 2001.

2) Wijnberg, K. M. and Terwindt, J.H. J. : Extracting decadal morphological behaviour from highresolution, long-term bathymetric surveys along the Holland coast using eigenfunction analysis,
Marine Geology, Vol. 126, 1-4, pp. 301-330, 1995.

3) Miller, J.K. and Dean, R.G. : A simple new shoreline change model, Coastal Eng., Vol. 51, pp. 531-556, 2004.

4) 加藤一正, 柳嶋慎一, 村上裕幸, 未次宏児 : 短期汀線 変動のモデル化の試み, 第 34 回海岸工学講演会論文 集, pp. 297-301， 1987.

5) 柴山知也, 柏木幹雄, 岡安章夫 : 砕波帯内長周期波の 漂砂量への効果, 海岸工学論文集, 第 39 巻, pp. 316320, 1992.

6) 加藤一正, 柳嶋慎一：長周期波によるバームの侵食, 土木学会論文集, No. 452/II-20，pp. 41-50， 1992.

7) 加藤一正, 柳嶋慎一, 栗山善昭, 磯上知良, 村上裕幸, 藤田誠: 砕波帯内の底質粒度の変動特性 波崎海洋観 測施設における現地観測, 港湾技術研究所報告, 第 29 巻, 第 2 号, pp. 37-61, 1990.

8) 永井紀彦：全国港湾海洋波浪観測 30 力年統計 （NOWPHAS1970-1999），港湾空港技術研究所資料，No. 1035, 388p, 2002.

9）鈴木崇之, 栗山善昭 : 汀線位置の長周期変動に対す る汀線変化量と波浪エネルギーおよび沿岸流速との関 係, 土木学会論文集 B, Vol.64, No. 4, pp. 280-290, 2008.

10）（財）沿岸開発技術研究センター：沿岸波浪・海象 観測データの解析・活用に関する解説書, pp. 70 , 2000.

11) 栗山善昭, 伊東啓勝：波崎海洋研究施設で観測され た断面変化の卓越周期の変動特性, 海岸工学論文集, 第 51 巻, pp. 516-520, 2004.

12)砂村継男：自然海岸における汀線位置の時間的変化 に関する予測モデル, 第 27 回海岸工学講演会論文集, p. 255-259, 1980.

13) Kench, P. S. and Brander, R.W. : Response of reef island shorelines to seasonal climate oscillations: South Maalhosmadulu atoll, Maldives, J. Geophys. Res. F: Earth Surface, Vol.111, 1, F01001, doi:10. 1029/2005JF000323, 2006.

14）鈴木崇之, 栗山善昭：バームの形成侵食に着目した 短期地形変化モデル, 海岸工学論文集, 第 56 巻, pp. 576-580, 2009.

15) 加藤一正, 中村聡志, 池田直太 : 波の連なりと長周 期波の関連に関する現地観測, 海岸工学論文集, 第 37 巻, pp. 101-105, 1990. 